\title{
ФОРМУВАННЯ ЕКОНОМІЧНОЇ КУЛЬТУРИ СУСПІЛЬСТВА В СУЧАСНИХ УМОВАХ
}

Сучасна парадигма теоретичних поглядів на роль і місце людини у відтворювальному процесі передбачає високий рівень не лише загальної культури, але й економічної культури зокрема. В останні роки в Україні унаслідок децентралізаційної реформи змінюються управлінські акценти на посилення культурного, економічного, політичного розвитку територіальних громад. Це спонукає в сучасних умовах обґрунтувати нові підходи до вирішення проблеми формування економічної культури на місцях, вимагає від кожної особистості оновлених кваліфікаційних характеристик, високого рівня підготовки до професійної діяльності, якому імпліцитно притаманний компонент економічної культури. В таких нових економічних, фінансових, суспільно-політичних умовах кожна особистість (особливо молодь) повинна знайти своє місце в системі суспільного відтворення, реалізувати свій потенціал у досягненні високих результатів своєї діяльності. Тільки за таких умов є можливість сформувати найважливіші компоненти економічної культури. Кожне суспільство характеризується унікальними рисами економічної культури. В Україні рівень економічної культури визначається рівнем доходу на душу населення, сучасною економічною і військово-політичною ситуацією у державі, суспільними етичними нормами, суспільною і громадською мораллю, рівнем освіти громадян, показниками інформатизації суспільства. Однією із важливих функцій економічної культури виділено інформаційну у аспекті впливу цифровізації на економічний вибір громадян, посилення впливу цифрової трансформації. Сучасне суспільство може координувати свої дії лише за рахунок реалізації функцій економічної культури, завдяки чому відкривається прямий шлях до підвищення рівня добробуту людей.

Ключові слова: територіальна громада; держава; економічна культура; суспільство; сталий розвиток; стратегія.

Постановка проблеми. В останні кілька десятиліть
спостерігається тенденція культурного занепаду Звісно,
найімовірнішою причиною цього є низька якість життя, що, поряд із
низьким рівнем доходів населення й обмеженими економічними
можливостями, характеризується також низьким рівнем якості й


доступності різноманітних послуг, важливих для повсякденного життя - культурних, освітніх, дозвільних, охорони здоров'я. Зміни в економіці України вимагають вирішення цілої низки принципово нових завдань, одним з яких є максимально ефективна діяльність сучасного підприємства, яка має враховувати рівень економічної культури та сучасні системи мотивування праці. Економічна культура проявляється в економічній поведінці, проте має суто прагматичний характер. Необхідно виключити кваліфікацію економічної культури як об'єкта економічної теорії, оскільки будь-яка економічна теорія $€$ частиною економічної культури. Як і будь-яка культура, економічна має певні етнічні й соціальні ознаки, які характеризуються умовами життя суспільства й детерміновані цими умовами. Економічна культура накопичує норми, правила, образи економічної поведінки людей, що сформувалися в історичному розрізі, вона відбирає їх, вилучивши ті, які вже не відповідають новим умовам; передає, транслює ці «відібрані» правила і зразки економічної поведінки від минулих поколінь сучасним (через механізми соціалізаціі); одночасно з'являється багато нових зразків економічної культури й економічної поведінки в сучасних умовах (інноваційна функція).

Аналіз останніх досліджень і публікацій. Економічна культура як важливий чинник суспільного розвитку світових держав і людства загалом останнім часом усе більше цікавить економістів, психологів, культурологів, соціологів, філософів. У сучасній науковій літературі досить широко представлені різні погляди на сутність саме економічної культури та іï особливостей у взаємозв'язку 3 одноплановими категоріями. Окремі аспекти економічної культури перебували в контексті наукових інтересів економістів, соціологів, психологів, педагогів, представників різних шкіл і течій. Вони знайшли втілення у працях М. Владики, В. Доброштана, Т. Заславської, В. Москаленка, Н. Попадинця, Г. Ребрової, Р. Ривкіної, М.Ховрича. Проте, незважаючи на різноплановість проведених досліджень, наявний практичний досвід, на сьогодні недостатньо вивченими $€$ перспективи подальшого розгляду економічної культури як важливого фактора соціально-економічного прогресу, i як регулятора економічної поведінки людей. Вплив економічної культури на різні сфери суспільного життя сприяє розумінню ефективності, прогресивного характеру господарювання. Вочевидь, вона визначає й специфіку національної економіки, формує справжні управлінські якості менеджерів, розширює й удосконалює соціально-економічні фактори (якість умов праці, мотивація, компетентність, творча ініціатива, рівень знань, умінь, навичок 
працівників) будь-якого підприємства. Економічна культура бере безпосередню участь у формуванні професійних якостей особистості, у тому числі й у становленні ії цінностей, моралі, знань, етичних норм тощо. Все це зумовило актуальність даного дослідження.

Постановка завдання. Метою статті $є$ проаналізувати сутність поняття «економічна культура», співвідношення із загальним поняттям «культура», дослідження трансформації економічної культури в Україні в контексті глобалізації і євроінтеграційних прагнень України, окреслення тенденцій підвищення рівня економічної культури сучасного суспільства. Задля досягнення мети поставлено такі завдання: визначити сутність поняття «економічна культура»; розкрити основні фактори впливу на стан економічної культури в Україні; окреслити тенденції підвищення рівня економічної культури в Україні в сучасних мовах цифровізації й інформатизації. Завдяки наявності економічної культури етносоціальна група стає здатною виокремити із зовнішнього середовища підстави для самовідтворення й використовувати їх на практиці, оскільки постійні контакти етносоціальних груп між собою нівелюють властиві тій чи іншій групі ознаки, надаючи економічній культурі глобалізаційного характеру. В сучасних умовах засадами ефективного використання мотивації праці є: високий рівень оплати; використання високопрофесійної праці; відсутність зрівнялівки в оплаті; істотний престиж праці в державі, висока купівельна спроможність людини та її зацікавленість у підвищенні кваліфікації, всі вони також впливають на формування економічної культури особистості.

Виклад основного матеріалу. Свобода економічного вибору це прояв свободи в економічній сфері, можливість й здатність самостійно приймати рішення про види і засоби економічної діяльності. Економічна свобода $€$ фундаментом розвитку ринку $\mathrm{i}$ розвитку особистості. В основі економічної свободи $€$ економічні відносини. Економічна культура як форма ціннісного освоєння економічної дійсності передбачає вибір економічної ролі й розроблення моделей економічної поведінки, що здійснюють економічну свободу в конкретній економічній ситуації. Ринкова економічна культура передбачає вибір ринкової моделі економічної поведінки на основі системи цінностей, норм, потреб та інтересів суспільства. Цей вибір неможливий без врахування норм, що встановлює держава для кожного конкретного виду діяльності, але водночас передбачає невтручання державних структур в економічну діяльність виробника за умови неухильного дотримання ним цих норм. 
Науковий і практичний інтерес становить дослідження поняття «економічна культура». Зокрема, М.О. Ховрич розділяє поняття «економічна культура» на два складники, узагальнено визначає їі структуру так: «Економічна культура суспільства - це система цінностей і мотивів господарської діяльності, рівень і якість економічних знань, оцінок і дій людини, а також зміст традицій i норм, які визначають економічні відносини й поведінку. Економічна культура особистості органічно поєднує свідомість і практичну діяльність. Вона виявляє творчу спрямованість економічної активності людини у процесі професійної діяльності, виробництва, розподілу й споживання. Економічна культура особистості може відповідати економічній культурі суспільства в цілому, випереджати iï, але може й відставати від неї чи заважати їі розвитку» [13, C. 311]. Інша дослідниця, Г.О.Реброва, врахувавши кореляції культурних й економічних цінностей, регіональний і глобалізаційний масштаб, під поняттям «економічна культура» розуміє «міждисциплінарну категорію, яка позначає феномен сталого економічного розвитку певного суспільства (держави, країни, регіону) на основі конгломерату культурних цінностей, сучасних науково-технічних досягнень, традицій і норм, які регламентують культурно-економічні відносини, якість господарювання й культуру споживання, що підвищує якість життя, та синхронізують економічний профіль держави із глобалізаційним вектором розвитку їі економіки» [9, C. 45].

«Великий економічний словник» тлумачить поняття «економічної культури» як «системи цінностей й мотивацій господарської діяльності, шанобливе ставлення до будь-якої форми власності й комерційного успіху як до значного соціального досягнення, здобутку, неприйняття настроїв «зрівнялівки», створення й розвиток соціального середовища для підприємництва та інше» [10-11].

Економічна культура відображає рівень економічних свобод, характеризує потенціал ринкової економіки. Здатність економічної культури як частини культури взагалі до самовідтворення i самовідновлення пов'язують із економічною свободою. Взаємозв'язок економічної культури і економічної свободи в умовах ринку істотно розширюється.

Нині економічна культура стає основою ствердження і зростання економічної свободи. Тільки на основі економічної культури економічна свобода здійснюється у своїй багатовимірності й багатогранності. У поєднанні з економічною культурою економічна свобода виявляє себе у формі самоствердження суб'єктів ринкової 
економіки й розгортання їх можливостей, а отже, у розширенні та збільшенні потенціалу ринкової економіки. У вільному економічному самовияві суб'єктів господарювання в умовах ринкової економіки обов'язково присутня відповідальність за всі дії в сфері економіки.

У здійсненні економічної свободи (в акті вибору) активність суб'єкта та його самообмеження тісно між собою пов'язані. Відповідальність за вибір для суб'єкта - це, насамперед, самообмеження у можливості здійснення цього ж вибору повторно. Економічний вибір - це безповоротний акт: обравши конкретний вид економічної поведінки і конкретний вчинок, що $€$ початком для здійснення вибраної економічної поведінки, суб'єкт економічних відносин не може використати одночасно й інші варіанти.

Економічна культура як узагальнений економічний досвід людини надає змістовності економічній свободі й творчості в умовах ринку і підтримує реальність вибору економічної поведінки. Разом із тим економічна культура пропонує форми здійснення людиною їі вільних творчих зусиль саме у сфері економіки. Основні функції економічної культури репрезентує табл. 1.

Таблиця 1

Основні функції економічної культури та їх сутнісна характеристика

\begin{tabular}{|c|c|c|}
\hline $\begin{array}{l}\text { № } \\
3 / \pi\end{array}$ & Назва функції & Сутність функції економічної культури \\
\hline 1 & $\begin{array}{l}\text { Нормативно- } \\
\text { регулювальна }\end{array}$ & $\begin{array}{l}\text { Забезпечення усталеності економічного життя шляхом } \\
\text { систематизації економічної поведінки й можливості } \\
\text { соціально-економічних акторів конструктивно й своєчасно } \\
\text { вирішувати назрілі економічні проблеми через структури } \\
\text { економічних інститутів }\end{array}$ \\
\hline 2 & Комунікативна & $\begin{array}{l}\text { Забезпечує спадкоємність економічного досвіду, тим } \\
\text { самим здійснює зв'язок між різними поколіннями. Дана } \\
\text { функція реалізує співпрацю між усіма членами суспільства } \\
\text { у вирішенні завдань економічної безпеки й національного } \\
\text { самозбереження, самобутності, економічного прогресу й } \\
\text { національного відродження }\end{array}$ \\
\hline 3 & Інтег & $\begin{array}{l}\text { Здійснюється, з одного боку, завдяки соціалізації молодих } \\
\text { поколінь, трансляцію укорінених в економічній культурі } \\
\text { цінностей і зразків поведінки, з іншого-завдяки існуючим } \\
\text { економічним цінностям, нормам, традиціям, ідеалам, } \\
\text { звичкам економічна культура спричиняє певний консенсус } \\
\text { у суспільстві, узгодження між різними суб'єктами } \\
\text { економічного процесу }\end{array}$ \\
\hline 4 & Інноваційна & $\begin{array}{l}\text { Здатність економічної культури до сприйняття нових } \\
\text { елементів культурного досвіду, завдяки цьому } \\
\text { утворюються нові форми господарювання, що } \\
\text { забезпечують ї̈ саморозвиток й розвиток економічних } \\
\text { інститутів і інституцій при одночасному збереженні } \\
\text { основних базовихцінностей }\end{array}$ \\
\hline
\end{tabular}


продовження табл. 1

\begin{tabular}{|l|l|l|}
\hline 5 & Інформативна & $\begin{array}{l}\text { Цифрова економіка вимагає нового рівня інформаційної й } \\
\text { економічної культури. Цифровізація усіх сфер суспільно- } \\
\text { політичного життя стає невід'ємною складовою розвитку } \\
\text { сучасного суспільства, формування цифрової грамотності, } \\
\text { тощо. Все це формує економічну культуру нового покоління } \\
\text { і нового рівня на основі цифрової грамотності суспільства та } \\
\text { загальної інформатизації }\end{array}$ \\
\hline
\end{tabular}

Джерело: узагальнено й доповнено за [1-4; 8-13].

Цифровізація розвивається в останнє десятиліття шаленими темпами: розвиток Інтернету, мобільних комунікацій, різноманітних онлайн-сервісів виступає базовим інструментом формування цифрової економіки. Усі ці процеси впливають на не лише на всі сектори економіки і соціальної діяльності, освіту, виробництво, охорону здоров'я, фінанси, транспорт, але й на формування економічної культури суспільства.

Економічна культура формується специфічними соціальноекономічними процесами і, у свою чергу, справляє на всю сукупність економічних процесів певного суспільства значний вплив. Кожній економічній системі відповідає особлива базова модель економічної культури, яка в кожній конкретній державі здатна виявлятися в національних специфічних формах. Немає «гарних» і «поганих» економічних культур, $\epsilon$ культури функціональні або дисфункціональні порівняно з економічною системою.

Отже, економічна культура $€$ сукупністю прогресивних гуманістичних матеріально-духовних досягнень людей і цінностей у різних сферах соціально-економічної діяльності, що сприяє розвитку ринкових відносин і формує поведінку особистості у межах ринку.

На економічну культуру в Україні впливають різні фактори, переважно іï стан $€$ результатом сформованої впродовж століть мотивів та установок, системи цінностей, а також етики ведення економічної діяльності, побудованої на прогресивних їі формах. Позитивістський підхід, яким пронизана сучасна економічна культура української нації, охоплює такі феномени, як «ноосферна економіка» i «ноосферне мислення» в контексті бережливого виробництва; відхід від «сліпого споживацтва», активізація справедливості на засадах «об'єктивного консумеризму»; поступова заміна культу «кількісного споживання» на «збереження для нащадків» тощо [7-11].

Цілком правильне твердження, що економічна культура суспільства залежить від державної інституціональної політики. Так, відомо, що більшість українців покладає усю відповідальність за свій 
матеріальний стан на державу. Водночас, якщо раніше українці готові були сприймати все, як $€$ (не полишаючи надію на краще життя), то тепер вони прямують у Європу не чекаючи цих змін (понад 3 млн осіб виїхали на заробітки до європейських країн: Чехії, Польщі, Італії, Німеччини та ін. [1; 6].

В Україні надзвичайної популярності набула Sharing Economy (економіка суспільного споживання), довіра при обміні, етики вторинного використання, підвищення коефіцієнту корисності речі, колективізація мобільності тощо. В сучасних умовах українці застосовують такі шерінгсервіси, як Rent a brand, Nextbike, Getmancar, а також Airbnb и Uber. У перспективі будуть створені Fonсервіси, які дозволятимуть українцям ділитися WiFi безкоштовно. B результаті такого розподілу буде сформовано нову соціо-економічну модель, яка повинна «еволюціонувати» від споживання товарів до споживання переважно послуг. Варто зазначити, що нині в Україні $€$ низький рівень економічної свободи (Україні належить 135 місце у світі) [12]. Це певним чином обмежує з боку держави свободи бізнесу і свободу трудових стосунків. У підсумку все це дозволяє прийти до того висновку, що на рівні суспільства (де-юре) ми маємо достатньо високий рівень економічної культури, а на рівні держави (де-факто) цей рівень у напрямку його підвищення поки що недостатньо ініційований до змін. Підвищити рівень економічної культури в Україні можливо за рахунок відповідних інвестицій в економіку знань, інтелектуальну економіку, креативну економіку, самоосвіту

Висновки. Сучасна економічна культура, крім елементів суб'єктивного світу, охоплює й такі компоненти, як норми й діючі «правила гри», вербальні реакції, моделі масової економічної поведінки, економічну символіку та знакову систему, що виражаються не тільки словесно, але й за допомогою інших засобів і форм. Ринок здійснює суттєвий вплив на економічну культуру, що виявляється в таких аспектах: по-перше, економічна культура відображає рівень економічних свобод, характеризує потенціал ринкової економіки; по-друге, тип економічних відносин, форми господарювання впливають на зміст і форми економічної культури та культуротворчого процесу. При цьому слід зважати як на загальні світові тенденції розвитку економічної культури людства як такої (оскільки українське суспільство у період трансформації не залишається осторонь загальних тенденцій сучасного цивілізаційного й інформаційного розвитку), так і на певну специфіку, яка характеризує саме вітчизняну економічну культуру.

Без сумніву, не можна говорити поки що про високий рівень економічної культури в Україні. Українське суспільство, прагнучи 
відповідати економічній культурі сучасного цивілізованого (цифрового, інформатизованого) світу, вже не дозволяє «дрейфувати» собі в інертній власній економічній культурі. Тому правильна оцінка трудових ресурсів, розумне їх використання, налагодження системи швидкої адаптації населення (трудових ресурсів) до кон'юнктури ринку, створення соціально-комфортних умов для самореалізації особистості $€$ першочерговими завданнями в мотиваційній діяльності. Саме тому, на рівні держави має бути зроблене все можливе, аби українське суспільство відчуло омріяну економічну свободу, передусім збагативши себе та розвіявши тим самим наявні стереотипи.

Отже, економічна культура $€$ підсистемою загальної національної культури й тісно пов'язана з іншими їі складовими: правовою, політичною культурою, моральною, релігійною та іншими. Економічна культура є багатовимірним явищем, яке складається як із раціональних, так й ірраціональних складових. Вона містить такі базові елементи, як економічні цінності й норми, сформовані й поширені в певному суспільстві економічні стереотипи, ідеї, концепції й переконання, економічні традиції, а також установки й орієнтації людей щодо існуючої економічної системи в цілому, певних важливих «правил гри» і принципів взаємовідносин особистості й економічних інститутів.

1. Попадинець Н.М. Напрями реформування сфери культури в умовах секторальної децентралізації. Регіональна економіка : науково-практичний журнал. 2017. № 3 (84). С. 116-122. 2. Децентралізація влади. Реформа децентралізації влади. URL: decentralization.gov.ua. (дата звернення: 07.06.2021). 3. Владыка М. В. Формирование основ экономической культуры старшеклассников : дисс. .... канд. пед. наук : 13.00.01. Белгород, 1998. 217 с. 4. Доброштан В. М. О некоторых аспектах экономической культуры общества и личности. Государственный советник. 2013. № 2. С. 53-64. 5. Заславская Т. И., Рывкина Р. Р. Социология экономической мысли: очерки теории. Новосибирск : Наука, Сиб. отд-ние, 1991. 448 с. 6. До уваги ЗМІ: цифра про 12 мільйонів українських заробітчан за кордоном не відповідає дійсності. URL: https://www.msp.gov.ua/news/16528.html. (дата звернення: 25.03.2021). 7. Москаленко В. В. Соціально-психологічні засади економічної культури особистості. Соціальна психологія. 2007. № 4. С. 3-16. 8. Москаленко В. В., Шайгородський Ю. Ж., Міщенко О.О. Економічна культура особистості: соціально-психологічний аспект. Київ : Вид-во «Центр соціальних комунікацій», 2012. 348 с. 9. РеброваГ. О. Формування економічної культури майбутніх учителів гуманітарних спеціальносттей засобами акмеологічних технологій : дис. ... канд. пед. наук : 13.00.04. Одеса, 2020. 292 с. 10. Философский энциклопедический словарь / редкол. : С. С. Аверинцев, Э.А. Араб-оглы, Л.Ф. Ильичев и др. 2-е изд. Москва : Сов. энциклопедия, 1989. 815 с. 11. Філософський енциклопедичний словник / В.І. Шинкарук (гол. ред.). Київ : Абрис, 2002. 742 с. 12. Україна посіла останнє місце за рівнем економічної свободи 
в Європі. URL: https://www.rbc.ua/ukr/news/ukraina-zanyala-poslednee-mesto-urovnyuekonomicheskoy-1599730653.html (дата звернення: 25.03.2021).13. Ховрич М. 0. Формування економічної культури майбутніх вчителів технологій при викладанні дисциплін електротехнічного профілю. Вісник Чернігівського національного педагогічного університету. Сер. Педагогічні науки. 2017. Вип. 144. С. 311-313.

\section{REFERENCES:}

1. Popadynets N. M. Napriamy reformuvannia sfery kultury $v$ umovakh sektoralnoi detsentralizatsii. Rehionalna ekonomika : naukovo-praktychnyi zhurnal. 2017. № 3 (84). S. 116-122. 2. Detsentralizatsiia vlady. Reforma detsentralizatsii vlady. URL: decentralization.gov.ua. (data zvernennia: 07.06.2021). 3. Vladyika M. V. Formirovanie osnov ekonomicheskoy kulturyi starsheklassnikov : diss. .... kand. ped. nauk : 13.00.01. Belgorod, 1998. 217 s. 4. Dobroshtan V. M. 0 nekotoryih aspektah ekonomicheskoy kulturyi obschestva i lichnosti. Gosudarstvennyiy sovetnik. 2013. № 2. S. 53-64. 5. Zaslavskaya T. I., Ryivkina R. R. Sotsiologiya ekonomicheskoy myisli: ocherki teorii. Novosibirsk: Nauka, Sib. otd-nie, 1991. 448 s. 6. Do uvahy ZMl: tsyfra pro 12 milioniv ukrainskykh zarobitchan za kordonom ne vidpovidaie diisnosti. URL: https://www.msp.gov.ua/news/16528.html. (data zvernennia: 25.03.2021). 7. Moskalenko V. V. Sotsialno-psykholohichni zasady ekonomichnoi kultury osobystosti. Sotsialna psykholohiia. 2007. № 4. S. 3-16. 8. Moskalenko V. V., Shaihorodskyi Yu. Zh., Mishchenko 0. O. Ekonomichna kultura osobystosti: sotsialnopsykholohichnyi aspekt. Kyiv : Vyd-vo «Tsentr sotsialnykh komunikatsii», 2012. 348 s. 9. Rebrova H. O. Formuvannia ekonomichnoi kul tury maibutnikh uchyteliv humanitarnykh spetsialnos tei zasobamy akmeolohichnykh tekhnolohii : dys. ... kand. ped. nauk: 13.00.04. Odesa, 2020. 292 s. 10. Filosofskiy entsiklopedicheskiy slovar / redkol. : S. S. Averintsev, E. A. Arab-oglyi, L. F. Ilichev i dr. 2-e izd. Moskva : Sov. entsiklopediya, 1989. 815 s. 11. Filosofskyi entsyklopedychnyi slovnyk / V. I. Shynkaruk (hol. red.). Kyiv : Abrys, 2002. 742 s. 12. Ukraina posila ostannie mistse za rivnem ekonomichnoi svobody $v$ Yevropi. URL: https://www.rbc.ua/ukr/news/ukraina-zanyala-poslednee-mesto-urovnyu-

ekonomicheskoy-1599730653.html (data zvernennia: 25.03.2021). 13. Khovrych M. O. Formuvannia ekonomichnoi kultury maibutnikh vchyteliv tekhnolohii pry vykladanni dys tsyplin elektrotekhnichnoho profiliu. Visnyk Chernihivskoho natsionalnoho pedahohichnoho universytetu. Ser. Pedahohichni nauky. 2017. Vyp. 144. S. 311-313.

Yakymchuk A. Yu. [1; ORCID ID: 0000-0002-5038-5215], Doctor of Economics, Professor

${ }^{1}$ National University of Water and Environmental Engineering, Rivne

\section{FORMATION OF ECONOMIC CULTURE OF SOCIETY IN MODERN CONDITIONS}

The modern paradigm of theoretical views on the role and place of man in the reproductive process involves a high level not only of general 
culture but also of economic culture in particular. In recent years, as a result of decentralization reform in Ukraine, managerial emphasis on strengthening the cultural, economic and political development of territorial communities has changed. This encourages in modern conditions to justify new approaches to solving the problem of economic culture on the ground, requires from each individual updated qualifications, a high level of preparation for professional activity, which implicitly has a component of economic culture. In such new ecological, financial, socio-political conditions, each individual (especially young people) must find their place in the system of social reproduction, realize their potential in achieving high results of their activities. Only under such conditions is it possible to form the most important components of economic culture. Each society has been characterized by unique features of economic culture. In Ukraine, the level of economic culture is determined by the level of per capita income, the current economic and military-political situation in the country, social ethics, public and public morality, the level of education of citizens, indicators of informatization of the neighborhood. One of the important functions of economic culture is informational in terms of the impact of digitalization on the economic choice of citizens, strengthening the impact of digital transformation. Modern society can coordinate its actions only through knowledge of the functions of economic culture, which opens a direct path to improving the well-being of society.

Keywords: territorial community; state; economic culture; society; sustainable development; strategy.

Якимчук А. Ю. [1; ORCID ID: 0000-0002-5038-5215], д.э.н., профессор

${ }^{1}$ Национальный университет водного хозяйства и природопользования, г. Ровно

\section{ФОРМИРОВАНИЕ ЭКОНОМИЧЕСКОЙ КУЛЬТУРЫ ОБЩЕСТВА В СОВРЕМЕННЫХ УСЛОВИЯХ}

Современная парадигма теоретических взглядов на роль и место человека в воспроизводственном процессе предполагает высокий уровень не только общей культуры, но и культуры экономической в частности. В последние годы в Украине вследствие децентрализационной реформы меняются управленческие акценты на усиление культурного, экономического, политического развития территориальных общин. Это побуждает в современных условиях применить новые подходы к решению проблемы формирования экономической культуры на местах, требует от каждой личности обновленных квалификационных характеристик, высокого уровня 
подготовки к профессиональной деятельности, которому имплицитно присущи компоненты экономической культуры. В таких новых экономических, финансовых, общественно-политических условиях каждая личность (особенно молодежь) должны найти свое место в системе общественного воспроизводства, реализовать свой потенциал в достижении высоких результатов своей деятельности. Только при таких условиях является возможным сформировать важнейшие компоненты экономической культуры. Каждое общество характеризуется уникальными чертами экономической культуры. В Украине уровень экономической культуры определяется уровнем дохода на душу населения, современной экономической и военно-политической ситуацией В государстве, общественными этическими нормами, общественной моралью, уровнем образования граждан, показателями информатизации общества. Одной из важных функций экономической культуры выделено информационную в аспекте влияния цифровизации на экономический выбор граждан, усиление влияния цифровой трансформации. Нынешнее общество может координировать свои действия только за счет знания функций економической культуры, благодаря чему открывается прямой путь к повышению уровня благосостояния населения.

Ключевые слова: территориальная община; государство; экономическая культура; общество; устойчивое развитие; стратегия. 